Borneo Journal of Science \& Technology, Volume (2), Issue (2), Pages: 06-10

DOI: http://doi.org/10.3570/bjost.2020.2.2-02

e-ISSN: 2672-7439

(C) 2018, UCTS Publisher.

\begin{tabular}{lll}
\hline Submitted: $06^{\text {th }}$ November 2019 & Accepted: $01^{\text {st }}$ June 2020 & Published: $31^{\text {th }}$ July 2020
\end{tabular}

\title{
Carbon Stock of Necromass in Harvested Forest of Gunung Basor, Kelantan
}

\author{
"Norashikin Fauzi, Nik Norain Nik Hassan, Musfiroh Jani, Amal Najihah Muhamad Nor, Siti Aisyah \\ Nawawi, Kamarul Arifin Kambali@Hambali, Muhammad Firdaus Abd.Karim \\ Faculty of Earth Science, Universiti Malaysia Kelantan (UMK), Jeli Campus, 17600 Jeli, Kelantan
}

\begin{abstract}
The information on the carbon sequestration potential and associated dynamics of necromass in the east coast of Malaysia particularly in Kelantan is scanty. No prior studies have been carried out to quantify the above ground biomass of necromass in Kelantan. The decrease of live tree biomass in response to selective timber harvesting within the vicinity may lead to an increase of necromass stock. Therefore, this study was executed to estimate the carbon stocks of necromass of harvested tropical forest. Necromass and carbon stocks were measured in two sampling plots of $200 \mathrm{~m}^{2}$ in Gunung Basor, Kelantan, Malaysia. All dead standing trees; trunks; dead trees on the ground; stumps with diameter $>5 \mathrm{~cm}$ and length of $>0.5 \mathrm{~m}$ were sampled. The total necromass recorded within the study area was 124.4 Mg ha ${ }^{-1}$ whilst a total of $62.2 \mathrm{Mg} \mathrm{ha}^{-1}$ carbon stock was estimated from 12 different diameter size classes. Out of 803 necromass samples, the highest carbon stock $\left(18.5 \mathrm{Mg} \mathrm{ha}^{-1}\right)$ was represented by $1 \%$ of fallen dead tree with dbh more than $55 \mathrm{~cm}$. About 21\% ( $\mathrm{n}=169)$ necromass contributed the second largest pool of carbon stock $(42.7 \mathrm{Mg}$ $\left.\mathrm{ha}^{-1}\right)$. Meanwhile, $79 \%(\mathrm{n}=634)$ of necromass was accounted for the lowest carbon sock $\left(1.0 \mathrm{Mg} \mathrm{ha}^{-1}\right)$ in the study area. The high necromass stocks in this study site may suggests that the flux of carbon dioxide by virtue to decomposition process may contribute to 30 to $40 \%$ of gross carbon dioxide efflux in the future. This study is vital in providing data on the carbon storage capacity of tropical forests in Kelantan and may as well aid in the decision making processes for sustainable forest management.
\end{abstract}

Keywords: Necromass, Carbon Stock, Harvested Forest

\section{INTRODUCTION}

Necromass is a term for dead portions of trees and branches. The death and subsequent decomposition of trees is an important component in the forest ecosystem carbon cycling and directly tied to the forest structure [6]; [9]. Carbon stored in necromass is one of the five carbon pools identified by the Intergovernmental Panel on Climate Change that should be measured and monitored for carbon book-keeping [26]. Accurate accounting of these pools is essential for mitigation, e.g. via REDD+ (reducing emissions from deforestation and degradation + enhancing forest carbon stocks).[16]

As carbon storage, much attention has been given to living above ground biomass as compared to woody coarse debris or necromass. The majority of studies investigating causes of spatial variation in biomass and carbon stocks of tropical forests remain focused on living trees [14]; [21]; [11], with the assumption that these represent the largest fraction of total above-ground biomass [17]. The dynamics of necromass production are poorly understood and quantified in tropical forest
[7]. Yoda and Kira [27] estimated $22.5 \mathrm{Mg} \mathrm{C} \mathrm{ha}^{-1}$ of necromass in Pasoh, Malaysia.

As tropical forests in Malaysia are crucial to carbon cycling and sequestering on a global scale, precise estimation is vital to ascertain the major role of necromass engages in contributing carbon stocks to conservation. The variation in necromass stocks depend on several factors such as topography affecting tree mortality [8] and the land use history and management of an area [7]; [12]. The practice of selective harvesting which is a major land use change process has eventually accelerated the necromass stocks in Malaysian tropical forests.

The information on the carbon sequestration potential and associated dynamics of necromass in the east coast of Malaysia particularly in Kelantan is scanty. No prior studies have been carried out to quantify the above ground biomass of necromass in Kelantan. The decrease of live tree biomass in response to selective timber harvesting within the vicinity may lead to an increase of necromass stock. Therefore, this study was carried out to estimate the biomass and carbon storage of necromass of harvested tropical forest in Gunung Basor, 
Kelantan, Malaysia. This study is vital in providing data on the carbon storage capacity of tropical forests in Kelantan and may as well aid in the decision making processes for sustainable forest management.

\section{MATERIALS AND METHODS}

\section{Study area}

The area of Gunung Basor is approximately 40,613 ha and 34,763 ha of Gunung Basor was gazetted as permanent forest reserve. Another 5,850 ha of Gunung Basor was targeted as production forest [15]. According to Kelantan Forestry Department (2003), Gunung Basor had been logged mostly in the late 1970s to 1980 s by selective management system. The soil type varies according to the terrain conditions. The average maximum and minimum temperature of Gunung Basor is $32^{\circ} \mathrm{C}$ and $25^{\circ} \mathrm{C}$ with mean annual rainfall of 2750 $3000 \mathrm{~mm}$. Generally, there are three types of vegetation zonation in Gunung Basor, namely lowland dipterocarp, hill dipterocarp and montane forests. The study area was located on the hill dipeterocarp forest, $1045 \mathrm{~m}$ asl. (Source: Kelantan Forestry Department, 2003)

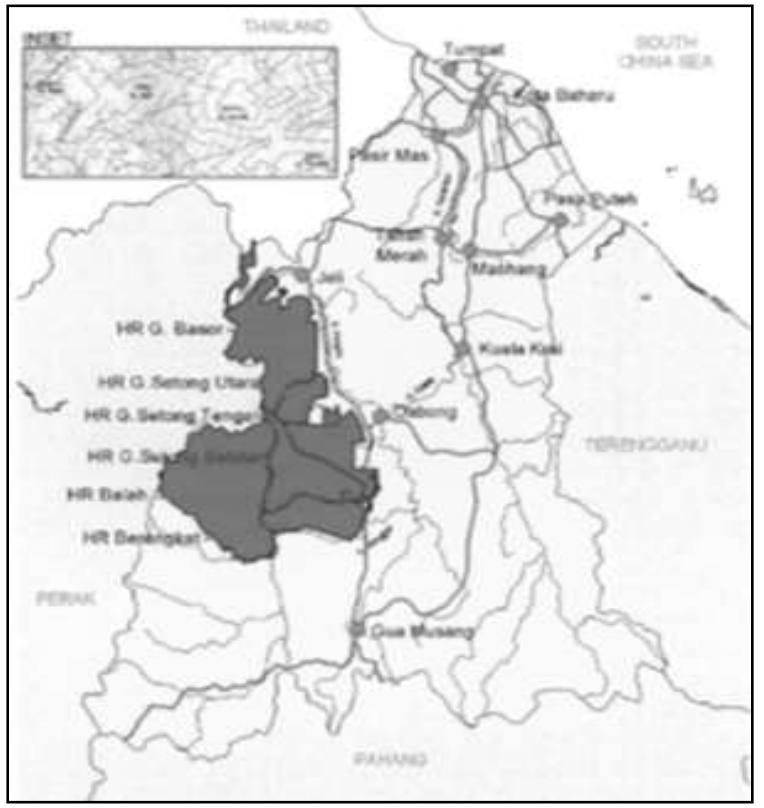

Figure 1: Map of the study area.

\section{Sampling technique and field measurement}

Two sampling plots of $200 \mathrm{~m}^{2}(5 \mathrm{x} 40 \mathrm{~m})$ were established due to the convenience to layout and measure. Necromass was measured using a fixed area plot sampling. Necromass or coarse woody debris is often divided into categories (1) fallen or downed necromass and (2) standing dead woods or snags [10]. In this study, all dead standing trees; trunks; dead trees on the ground; stumps with diameter $>5 \mathrm{~cm}$ and length of $>0.5 \mathrm{~m}$ were sampled. Each tree was measured for $\mathrm{dbh}$ (in $\mathrm{cm}$ ) by using a diameter tape whilst the height (in $\mathrm{m}$ ) was measured by using hypsonometer range. For subsequent analyses, to account for potential errors in $\mathrm{dbh}$ measurement, the measured tree dbh were binned into equal classes of $5 \mathrm{~cm}$ diameter each (e.g 0-5,5$10,10-15 \mathrm{~cm})$.

The biomass of necromass was calculated by using the following equation:

$$
\text { Biomass }=\pi \times \mathrm{D}^{2} \times \mathrm{h} \times 0.5 / 40
$$

Where, biomass was expressed as $\mathrm{h}=$ length, $\mathrm{D}=$ diameter, $0.5=$ specific gravity of tree [13].

Meanwhile, carbon stored in necromass was obtained as half of the dry mass, it was assumed that $50 \%$ of the dry mass was carbon [26].

\section{RESULTS AND DISCUSSION}

The total necromass recorded within the study area was 124.4 Mg ha ${ }^{-1}$ accounted by 803 samples. Figure 2 indicates the highest necromass $\left(36.9 \mathrm{Mg} \mathrm{ha}^{-1}\right.$ ) was estimated in fallen dead tree with a large diameter tree range of $122.6 \mathrm{~m}$. Whilst, the lowest necromass $(2.0 \mathrm{Mg}$ $\mathrm{ha}^{-1}$ ) was accounted by dead trees with smaller tree diameters ranging less than $5 \mathrm{~cm}$. Of these, $85.8 \mathrm{Mg} \mathrm{ha}^{-}$ ${ }^{1}$ of necromass was estimated among the dead trees with diameter ranges in between 5 to $55 \mathrm{~cm}$

A total of $62.2 \mathrm{Mg} \mathrm{ha}^{-1}$ carbon stock was estimated from 12 different diameter size classes. In Figure 3, out of 803 necromass samples, the highest carbon stock $\left(18.5 \mathrm{Mg} \mathrm{ha}^{-1}\right)$ was represented by $1 \%$ of fallen dead tree with dbh more than $55 \mathrm{~cm}$. Another 21\% (n=169) necromass contributed the second largest pool of carbon stock (42.7 $\left.\mathrm{Mg} \mathrm{ha}^{-1}\right)$. Meanwhile, 79\% (n=634) of necromass was accounted for the lowest carbon sock (1.0 $\left.\mathrm{Mg} \mathrm{ha}^{-1}\right)$ in the study area.

The estimates of necromass stock in harvested forest of Gunung Basor (124.4 Mg ha-1) was out of the spectrum recorded for lowland tropical forests [1]; 26 $\mathrm{Mg} \mathrm{ha}^{-1}$ [23] and $41 \mathrm{Mg} \mathrm{ha}^{-1}$ [8] previously found for lowland forests 


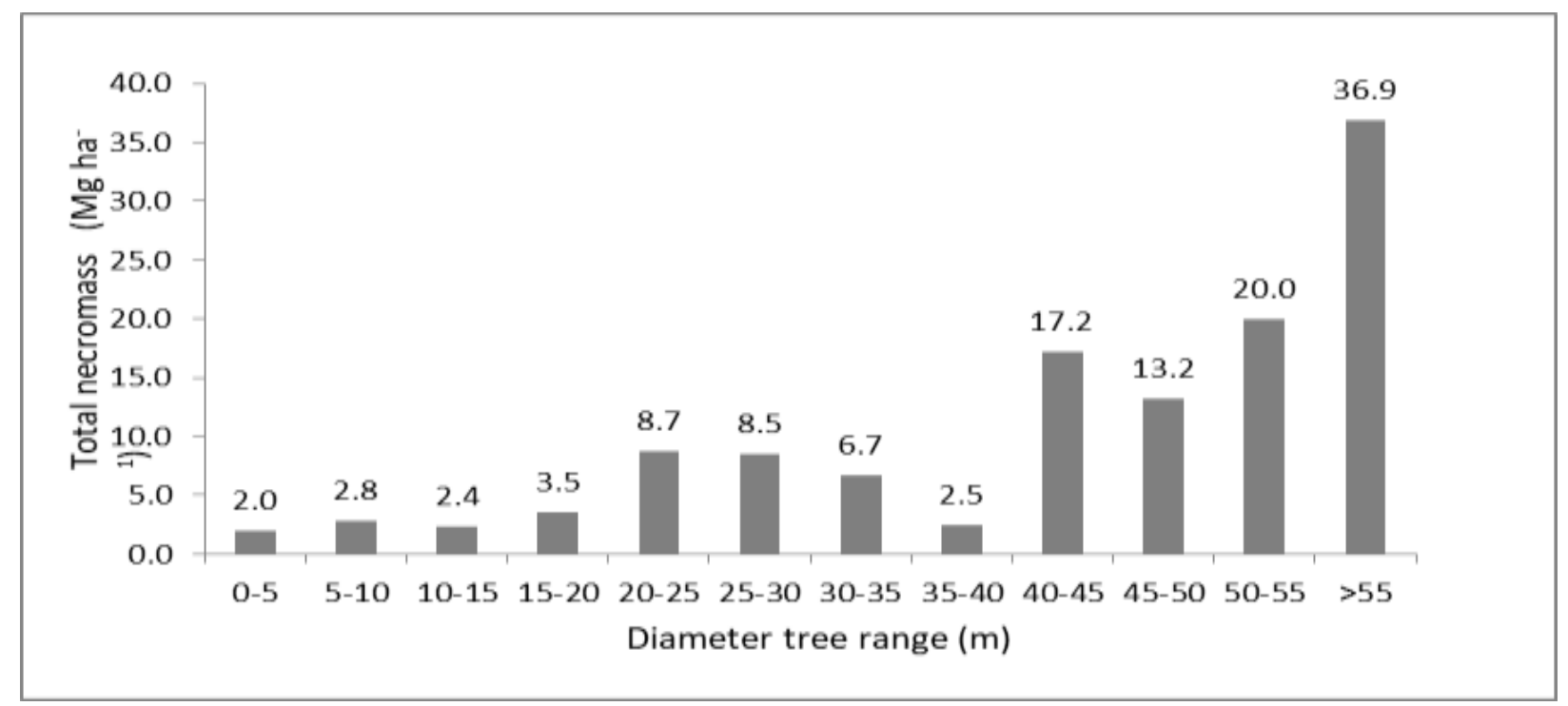

Figure 2: Total necromass of Gunung Basor harvested forest, estimated in different diameter sizes.

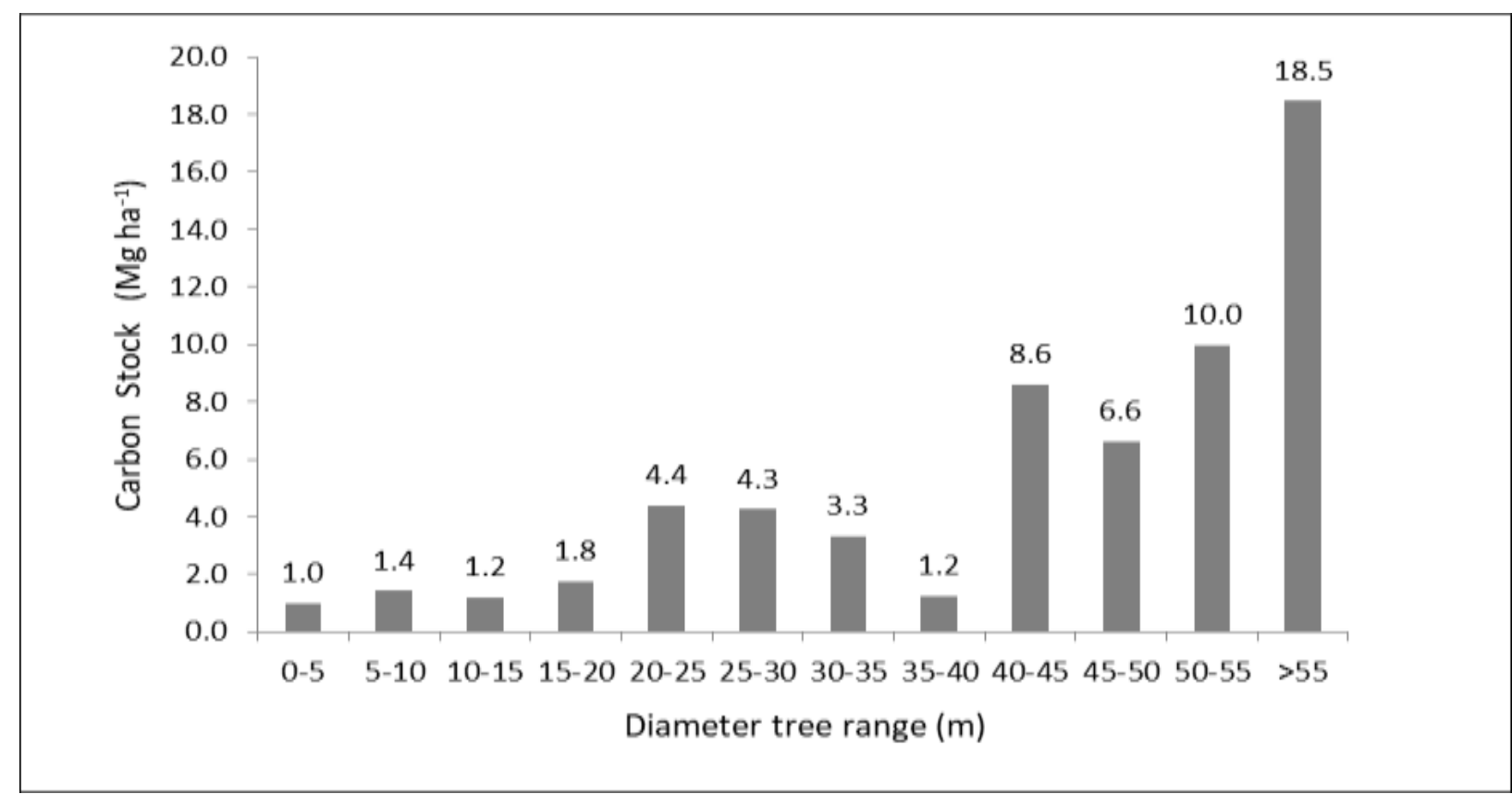

Figure 3: A carbon stock pool in different sizes necromass of Gunung Basor harvested forest.

in North Borneo. Gale [8] estimated necromass for pieces with $>20 \mathrm{~cm}$ diameter to be $45 \mathrm{Mg} \mathrm{ha}^{-1}$ in Belalong, Brunei; $41 \mathrm{Mg} \mathrm{ha}^{-1}$ in Danum, Sabah and 69 $\mathrm{Mg} \mathrm{ha}^{-1}$ in Andalau, Brunei . According to Delaney et al. [5], deadwood mass in undisturbed moist tropical forests has been estimated to be less than $10 \%, 15 \%$ [24] and $19 \%$ [22] of total above ground biomass stocks.

On contrary, the analysis in this study indicates the dead tree mass in harvested forest of Gunung Basor was approximately 30 to $40 \%$ higher than undisturbed forests even though the reduced impact logging (RIL) management had been strictly imposed. The study site was once been logged in late 1990s and been left untouched for almost 28 years as to comply with Selective Management System (SMS). There were several factors that may contribute to the high accumulation of necromass stocks within the study site, such as slow rate of decomposition of certain necromass components or species. The moist temperature and sometimes due to torrential rain will gradually abate the decomposition process. Eventually, as the time goes by, the new fallen dead trees due to disease or natural 


\section{Carbon Stock of Necromass in Harvested Forest of Gunung Basor, Kelantan}

disaster such as thunder strike will increase the accumulation of necromass stocks. Apart from that, the existence of previous harvested trails may also contribute to higher necromass stocks.

As meta-analyses suggest that selectively logged forests retain substantial biodiversity, carbon and timber stocks with once logged forest stands retaining $76 \%$ of their above ground carbon stocks one year after logging [20]. According to Berenguer et al. [2], large landscape assessments of above ground carbon changes along a disturbance gradient in tropical forests are rare. Carbon changes studies typically focus on assessments of either live tree or dead wood carbon [13]; [14]; [3]. Few studies that quantify both living and dead carbon stocks have often been carried out in primary forest stands alone [18] and [14]. According to Pfeifer et. al [19], the deadwood carbon stocks can represent a large proportion $(>50 \%)$ of above ground carbon stocks in human modified forests. Comprehensive studies of tropical necromass in tropical forests need to include both standing dead and smaller size class measurements (< $10 \mathrm{~cm}$ diameter) due to those will collectively contribute a large proportion of the overall necromass pool [19].

\section{CONCLUSION}

The analysis in this study indicates the dead tree mass in harvested forest of Gunung Basor was approximately 30 to $40 \%$ higher than undisturbed forests even though the reduced impact logging (RIL) management had been strictly imposed. The high necromass stocks in this study site may suggests that the flux of carbon dioxide by virtue to decomposition process may contribute to 30 to $40 \%$ of gross carbon dioxide efflux in the future. The high percentage of necromass stock recorded in this harvested forest reflected the low carbon storage in live trees. The carbon stocks of necromass only comprise $50 \%$ of the dry mass as compared to the live trees. Further improvement for efficient implementation on RIL management should be highly considered. Nevertheless, several environmental factors may contribute to this high accumulation of necromass stocks. This study is vital in providing data on the carbon storage capacity of tropical forests in Kelantan and may as well aid in the decision making processes for sustainable forest management.

\section{ACKNOWLEDGMENT}

We thank Jabatan Perhutanan Negeri Kelantan for granting the permission to execute our study and Universiti Malaysia Kelantan for SGJP grant provision R/SGJP/A08.00/00060A/002/2018/000482 to support this study.

\section{REFERENCES}

[1] Baker, T. R. et. al 2004. Variation in wood density determines spatial patterns in Amazonian forest biomassGlob. Change Biol. 10 545-62

[2] Berenguer, E. et al. 2014. A large-scale field assessment of carbon stocks in human-modified tropical forestsGlob. Change Biol. 20 3713-26

[3] Blanc L, Echard M, Herault B, Bonal D, Marcon E, Chave J and Baraloto C. 2009. Dynamics of aboveground carbon stocks in a selectively logged tropical forest Ecol. Appl. 19 1397-404

[4] Brown, J.K., 1974. Handbook for Inventorying Downed Woody Material. USDA Forest Service, Ogden, Utah, pp. 1-24.

[5] Delaney M, Brown S, Lugo A E, Torres-Lezama A and Quintero N B 1998 The quantity and turnover of dead wood in permanent forest plots in six life zones of Venezuela1 Biotropica $302-$ 11

[6] Denslow, J.S., 1987. Tropical rainforest gaps and tree species diversity. Ann. Rev. Ecol. Syst. $18,431-451$

[7] Eaton, J.M., Lawrence, D., 2006. Woody debris stocks and fluxes during succession in a dry tropical forest. Forest Ecol. Manage. 232, 46-55.

[8] Gale N 2000 The aftermath of tree death: coarse woody debris and the topography in four tropical rain forests Can. J. For. Res. 30 1489-93

[9] Harmon, M.E., Franklin, J.F., 1989. Tree seedlings on logs in Picea-Tsuga forests of Oregon and Washington. Ecology 70, 48-59.

[10] Harmon, M.E., Franklin, J.F., Swanson, F.J., Sollins, P., Gregory, S.V., Lattin, J.D., Anderson, N.H., Cline, S.P., Aumen, N.G., Sedell, J.R., Lienkaemper, G.W., Cromack, K., Cummins, K.W., 1986. Ecology of coarse woody debris in temperate ecosystems. Adv. Ecol. Res. 15, 133-302.

[11] Houghton R A, Hall F and Goetz S J 2009 Importance of biomass in the global carbon cycle J. Geophys. Res. Biogeosc. 114 G00E03

[12] Kauffman J B, Hughes R F and Heider C 2009 Carbon pool and biomass dynamics associated with deforestation, land use, and agricultural abandonment in the neotropics Ecol. Appl. 19 1211-22

[13] Keller M, Palace M, Asner G P, Pereira R and Silva J N M 2004 Coarse woody debris in undisturbed and logged forests in the Eastern Brazilian AmazonGlob. Change Biol. 10 784-95

[14] Malhi Y et al 2006 The regional variation of aboveground live biomass in old-growth 
Amazonian forests Glob. Change Biol. 12 110738.

[15] Kelantan Forestry Department. (2003). Jabatan Perhutanan Negeri Kelantan. Available from http://jpnk.kelantan.gov.my/index.

php?option=com_content\&view=article\&id=44 \&lang=my

[16] Martius, C., 1997. Decomposition of wood. In: Junk, Wolfgand, J. (Eds.), Ecological Studies 126. The Central Amazon Floodplain. Ecology of a Pulsing System. Springer, NYC

[17] Mertz O et al. 2012. The forgotten D: challenges of addressing forest degradation in complex mosaic landscapes under REDD+ Geogr. Tidsskr. J. Geogr. 112 63-76

[18] Nascimento H. E. M. and Laurance W. F. 2002. Total aboveground biomass in Central Amazonian rainforests: a landscape-scale study For. Ecol. Manage. 168 311-21

[19] Pereira R, Zweede .J, Asner, G. P. and Keller M. 2002. Forest canopy damage and recovery in reduced-impact and conventional selective logging in Eastern Para, Brazil For. Ecol. Manage. 168 77-89

[20] Pfeifer M, Lefebvre V, Edgar Turner 2015 Deadwood biomass: an underestimated carbon stock in degraded tropical forest?. Environmental Research Letter 10 1-9

[21] Putz F. E .et al. 2012. Sustaining conservation values in selectively logged tropical forests: the attained and the attainable Conserv. Lett. 5 296303

[22] Saatchi S, Houghton R A, Dos Santos Alvalá R C, Soares J V and Yu Y 2007 Distribution of aboveground live biomass in the Amazon basin Glob. Change Biol. 13 816-37

[23] Saldarriaga J G, West D C, Tharp M L and Uhl C 1988. Long-term chronosequence of forest succession in the upper Rio Negro of Colombia and Venezuela J. Ecol. 76 938-58

[24] Saner P, Loh Y Y, Ong R C and Hector A 2012 Carbon stocks and fluxes in tropical lowland dipterocarp rainforests in Sabah, Malaysian Borneo ed Chave J PLoS One 7 e29642

[25] Uhl C, Clark K, Dezzeo N and Maquirino P 1988 Vegetation dynamics in Amazonian treefall gaps Ecology 69 751-63

[26] Watson, R T, Noble I R, Bolin B, Ravindranath N H,Verardo D. J. and Dokken D. J. 2000. Land use, land-use change and forestry IPPC Report(www.ipcc.ch/pdf/specialreports/spm/srl-en.pdf)

[27] Woodall, Christopher W., Monleon, Vicente J. 2008. Sampling protocol, estimation, and analysis procedures for the down woody materials indicator of the FIA program. Gen. Tech. Rep. NRS-22. Newtown Square, PA: U.S. Department of Agriculture, Forest Service, Northern Research Station.

[28] Yoda, K., Kira, T. 1982. Accumulation of organic matter, carbon, nitrogen, and other nutrient elements in the soils of a lowland rainforest at Pasoh, Peninsular Malaysia. Jpn. J. Ecol. 32, 275-291. 